Scholedge International Journal of Multidisciplinary \& Applied Studies ISSN 2394-336X, Vol.05, Issue 02 (2018) Pg 17-26.

DOI: 10.19085/journal.sijmas05021
Published by: Scholedge Publishing

www.theSCHOLEDGE.org

Email: editorial@thescholedge.org

CPublisher

\title{
THE INNOVATIVE ACTIVITY OF THE BANKS
}

\author{
Assoc. Prof. Natiq Qurbanov Guseyn , PhD. Nurkhodzha Akbulaev Nazirhodjä, Turan Ahmedov \\ Faculty of Turkish World Management, Azerbaijan State University of Economics-UNEC, Baku, \\ Azerbaijan. \\ \#corresponding author.
}

\begin{abstract}
ABSTACT
Currently the bank sector plays an important role in the provision of innovative developments of the country economy. The solution of the task demands its competitiveness and innovative orientation of all financial-credit organizations in it's consistency. In connection with this first of all a great responsibility and importance lies on governments with banks. Mainly they'll play a fundamental role in the provision of high level investment activity in the economy in making financial support of a market infrastructure. Revolutionary changes in financial-credit sphere taking place in Azerbaijan Republic for the last decade caused high level dynamism of financial markets, specially of bank products market. During the short-term period of its development there was observed distribution of markets share among its participants, appearance of great amount of new participants, regular changes in the sphere of regulation market interrelationship by the government that served regular difference in additional inducements for fulfillment and change of existing spector of bank products. These processes integrally bring us to the bank activity sphere, having the "innovative" denomination.
\end{abstract}

The aim of the research is the handling and foundation of methodological position on analysis, formation of innovative bank technology, providing the enhancement of the bank business efficiency.

The subject of the research is the bank realizing innovative technology of bank service to natural persons at the modern stage development of home market economy.

The object of the research is organisational-economic aspects of innovative activity of banks and utilisation of innovative bank technology.

The theoretical and methodological basis of the research is the fundamental labours and scientific research results of national and foreign scientists in the sphere of theory and practice of innovative activity and banking, also local normative legal acts of commercial banks on investigated problem, publications in periodical and branch issues, materials of scientific-practical conferences and seminars.

Key words: innovation, banks, financing, management, economy.

\section{INTRODUCTION}

Effective activities of banks are the most important condition of further economic development of the country and in many respects predetermine growth rates of economy of the Azerbaijan Republic. In process of enhancement of market conditions of managing of a bank system there is a need of implementation of the innovative information technologies, modern methods and management models directed to increase of its competitiveness.

For achievement of long-term goals and a sustainable development of banks the modern innovative technologies allowing banks to enhance and increase efficiency of the rendered services, to create competitive advantages and to strengthen the market position have special value. Direct impact on development of innovative banking technologies is exerted by a modern situation in the financial markets. Deterioration in a condition of a bank 
system happens in connection with the world financial and economic crises. At the same time at a number of commercial banks the crisis situation with liquidity begins to develop and there are problems with settlement of liabilities which lead to reducing the contingent of bank employees, investments in development and implementation of innovative banking technologies. Unfortunately, many of these banks, make a mistake, refusing further investments in an innovation now.

Banking activity is the specific sphere of the economy having considerable distinctive features owing to which not all methods of involvement of consumers accepted in system of marketing of industrial companies can be realized by it. In particular, features of pricing on banking services do not allow many banks of a message full price fight against competitors. With respect thereto one of the main directions of involvement of clients by banks is enhancement of activities on the basis of development of new banking technologies, products and types of services.

Followings are characteristic of the present stage of development of the Azerbaijani banks: growth of noncash money turnover and demand of the population for the services connected with use of the plastic cards serving cashless payments and also new means of communication in case of management of the bank account. In these conditions their strategic development programs which are based on forming and effective use of innovative potential including development of new banking technologies, products and types of service become the determining factor urged to provide competitiveness of commercial banks of the Azerbaijan Republic. In our opinion implementation of these programs shall be carried out systematically, taking into account the existing features of bank management, balance of resource base and needs of clients both flowing, and potential.

\section{THEORETICAL BASES OF INNOVATIVE TECHNOLOGIES IN BANKACTIVITIES}

The present stage of development of a bank system of the Azerbaijan Republic is characterized by the high level of saturation of the market financial products and services and, as a result, the intensive competition between credit institutions. In such conditions the essential advantage is got by those credit institutions which are capable to develop and implement new technologies, to modernize a product row, to develop alternative channels of customer service that is to perform innovative process. In the context of this situation actual it is represented to trace tendencies based on which there was a development of innovative activities of the Azerbaijan Republics banks and to determine specifics of innovative process in the banking sector at the moment.

\section{Concept of Innovative activity}

The modern economic science treats the concept "innovations" (innovations) as "the resulting effect of innovative activities which has received the embodiment in the form of the new or advanced product implemented in the market, the new or advanced engineering procedure used in practical activities, or in new approach to social services".

Innovative activities are a complex of scientific, technological, organizational, financial and commercial actions directed to commercialization of the accumulated knowledge, technologies and the equipment. New or additional goods services or goods services with new qualities are result of innovative activities. Also innovative activities can be determined as activities for creation, development, distribution and use of innovations.

The separate direction of management - innovative management is devoted to questions of management of innovative activities (Goldstein G. Ja. 2004. 267s). Innovative activities are the activities directed to use and commercialization of results of scientific researches and developments for expansion and updating of the nomenclature and improvement of quality of products (goods, services), enhancement of technology of their production with the subsequent implementation and effective implementation on internal and the foreign markets, assuming the whole complex of scientific, technical, technological, organizational, financial and commercial actions which in the set lead to innovations.

Differentiate several types of innovations (Terenina A.S, Tonysheva L.L., 2012, www.rae.ru/forum2012):

- $\quad$ technical appear in production of products with the new or improved properties;

- technological arise in case of application of more perfect methods of production of products;

- organizational and managerial are connected with processes of optimum production organization, transport, sale and supply;

http://dx.doi.org/10.19085/journal.sijmas05021 
- information solve problems of the rational organization of information flows in the sphere of scientific and technical and innovative activities, increase of reliability and efficiency of receipt of information;

- social are directed to improvement of working conditions, the problem resolution of health care, education, culture.

\section{Innovations in Bank Activity}

In relation to article subject, creation of the banking product possessing more attractive consumer properties in comparison with offered earlier, or qualitatively new product capable to satisfy needs of his potential buyer not covered earlier, or use of more perfect technology of creation of the same banking product means.

Among the properties inherent in an innovation, it is possible to allocate the following characteristics:

- novelty;

- satisfaction of a market demand;

- commercial feasibility.

In scientific literature there were various points of view on a ratio of the concepts "banking product" and "banking service". If it agrees the first of them - these concepts practically do not differ among themselves, if it agrees the second - concepts are essentially distinguishable. Transition to accurate gradation of these concepts is inevitable though now it is still completely impracticable that is traced in modern literature. Banking service is the actions directed to satisfaction with bank of need of the client. Banking service is realized by means of sale of a banking product.

The banking product is fully complete complex of banking activities directed to satisfaction of need of the client and having the technological description.

The concept "innovations" is applicable to all innovations in all spheres of functioning of bank having a certain positive economic or strategic effect.

Bank innovations should be determined as result of the actions of bank directed to any positive changes in all fields of activity of bank and increase of efficiency of its activities. Fixed updates do innovative process by important means of preserving line items in the market.

Banking innovative technologies should be determined as set of the new bank acceptances and methods of the organization of bank influencing development of bank in all spheres of its activities and increasing efficiency of activities of bank (requirements satisfaction of clients, bank staff and its shareholders).

The choice of any strategy, including innovative, always implies creation of the individual organizational economic mechanism providing its implementation. Orientation of this mechanism, feature of functioning and structure of creation in many respects depend on the specifics of innovative processes determined by a typology of the innovations prevailing in the course of innovative activities of bank. To concretize the purposes and results of innovative activities, and also to systematize approach to a set of its possible manifestations, rather complete classification of innovations is necessary.

Considering various approaches of scientists to classification of bank innovations, on the basis of the analysis of their merits and demerits, and also taking into account dynamic changes which are dictated by practice of banking activity, it is possible to systematize the expanded classification of innovative technologies of commercial bank adequate to modern domestic economic reality. This classification covers all set of bank innovations in various cuts and determines comprehensive understanding of a subject of classification. In the author's opinion, it is reasonable to carry out classification of innovations and innovative technologies of commercial bank on the following classification signs (Rudko M. V. 2011, 11-13):

- technological parameters

- the origin reasons

- innovative potential

- impact amount 
- $\quad$ novelty degrees

- nature of the satisfied requirements

- emergence time

- in relation to development.

At the present stage the innovations connected directly with scientific and technical progress that is technological innovations are most widespread. Banking becomes more and more dependent on the latest information technologies. It is caused, first of all, by the strategy of development of innovations dominating today in banking business. Banks began to understand that efficiency of the sphere of banking services, its safety and appeal to clients can be provided only with electronic technology and automation of bank processes. This fact induces them to perform financing of carrying out research works in this area, their implementations in banking practice, than they also are guided in aspiration to increase in a market share and desire to succeed in competitive struggle.

All above-mentioned signs fully answer concept of a banking product, however in a type of ambiguity of the concept of innovative activities of bank, it is necessary to prove separately concept of "novelty" in relation to implementation of new banking products (Vikulov V. S., 2011,N-1):

- any product which is independently developed by bank for requirements satisfaction of clients and not having before analogs in the market is new;

- any product which is already available in a range of services of bank and used in one of the markets, but removed on another - also is new;

- any product implemented by bank on the basis of market research and an assessment of commercial feasibility of creation of the copy of the product which is already available in the market is new.

The above allows to draw unambiguously a conclusion that the concept "innovations" is applicable to all innovations in all spheres of functioning of bank having a certain positive economic or strategic effect as which example it is possible to consider a surplus of client base of bank, increase in a market share, cost reduction at carrying out any transaction type, etc. or create conditions for the above-mentioned. Innovative process, i.e. the process connected with creation, development and distribution of innovations covers all aspects of activity of bank: from development of the concept or idea before its practical implementation.

All innovative processes existing in bank can be subdivided into three logical groups (L.M. Gokhberg, 1996. $30-31)$ :

- Simple intra organizational innovative process, i.e. the process assuming creation and use of an innovation within the same bank. In this case the innovation does not take the form of a new banking product, and only enhances the production technology of already existing products or any service technology.

- The simple inter-organizational process providing forming of the new banking product intended for market promotion as a subject of purchase and sale.

- The expanded innovative process which is generally connected with forming of a complex banking product when during its creation the bank cooperates with the partners thereby redistributing innovative process between several participants. It is possible to give services of acquiring, system of remote control of the account, package provision of insurance services, etc. as an example.

In general, any innovative process in bank has cyclic nature. The activities having innovative process in the basis logically break up to the separate accurately expressed elements realized chronologically consistently, and often and different divisions of bank. Schematically the cycle of innovative process looks as follows (see fig. 1). 


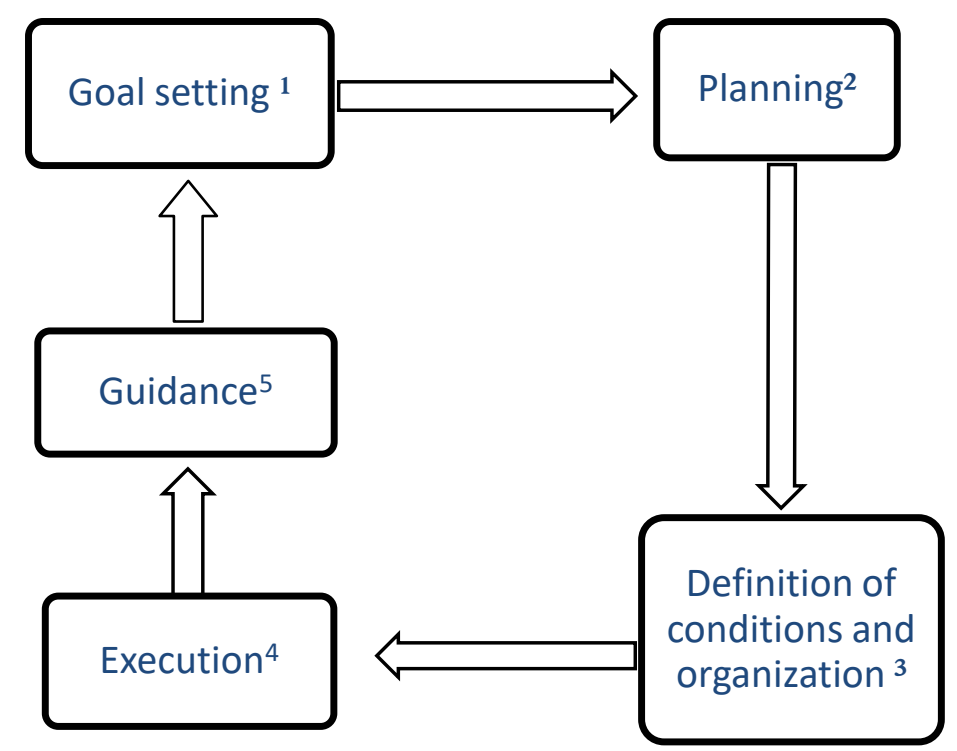
2011,N-1):

Each stage of innovative process is intended for the solution of a separate certain task (Vikulov V. S.,

- Emergence of idea and problem definition of the forthcoming innovative process.

- Scheduling of the actions and actions necessary for goal achievement.

- Determination of resource requirement (personnel, technological, material), necessary for implementation of innovative process, statement of local tasks before contractors.

- Carrying out by contractors (the bank employees responsible for carrying out innovative actions) of the actions connected with implementation of the tasks.

- Control, the analysis and adjustment of the carried-out actions. An efficiency evaluation of the innovative project, innovative management decisions, extra analytical work for refining of the plan of the subsequent actions for implementation of results of innovative process.

Bringing together data on innovative activities of credit institutions of Azerbaijan, it is necessary to mark out certain regularities of its origin and implementation. Here it is necessary to notice that questions of innovative management which become very actual at certain stages of functioning of credit institution are firmly connected with questions of strategic management. The ratio of these communications allows to consider innovative activities of bank in this aspect as dynamic interrelation of five management processes: the analysis of the environment, determination is more whole, the strategy choice, strategy accomplishment, an assessment and control vypolneniya3. The mentioned processes logically are continuation of each other as initially, during creation of credit institution, arise chronologically consistently. However, further in the course of its functioning they proceed in parallel on a fixed basis, and the present return interrelation between them causes accurately expressed influence of each of these processes on the others and on all their set in general. Schematically these interrelations can be presented in the form of the following structure (see fig. 2): 


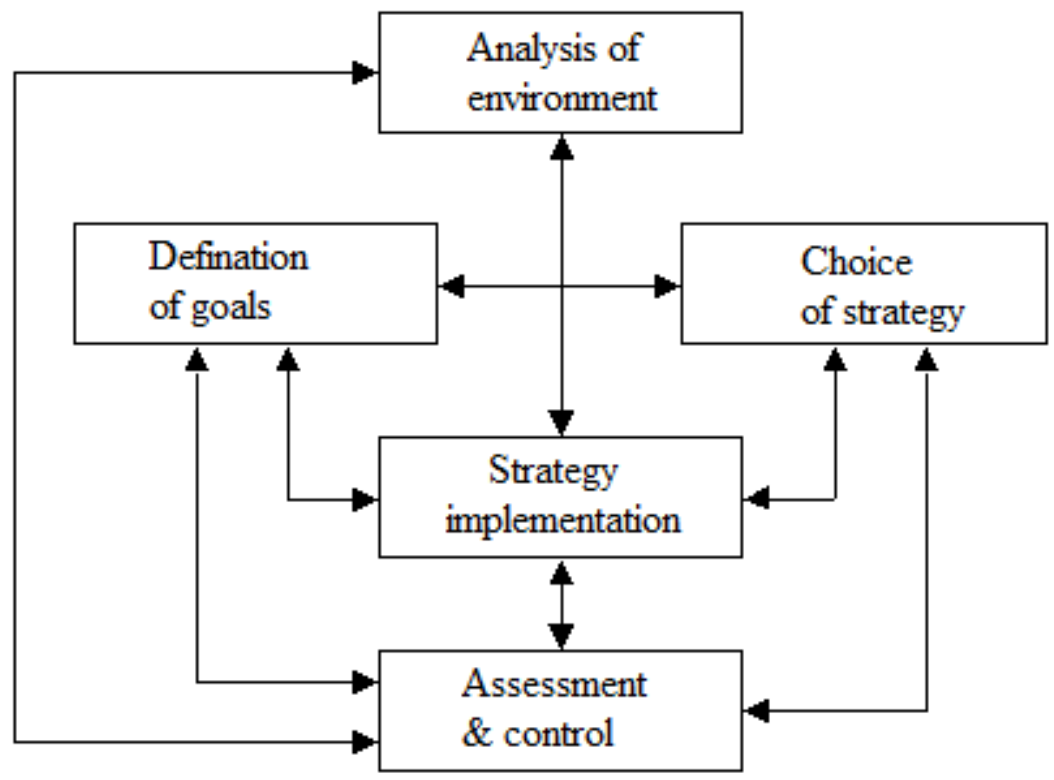

The analysis of the environment is always meant as initial management process during which prerequisites of the forthcoming activities are created, starting points for the choice of mission and determination is more whole, and also there is a market and product orientation of credit institution. The bank, as well as any system which is actively interacting with external environment (in particular, with the market environment), has a fundamental task of preserving and maintenance of balance of this interaction. The conclusion following from here is that generally the bank during the relations with elements of the environment is involved in three basic processes:

- receipt of resources from external environment (a so-called entrance);

- transformation of resources into a product (so-called transformation);

- transfer of the created product to external environment (exit).

Preserving balance between these sub-processes of activities of credit institution means a survival it in the market. Process of the analysis of the environment in this case is logically initial in a chain of elements of all innovative activities of bank. The current trend in the sharp shift of priorities taking place in the field of reduction to compliance of balance of an entrance exit towards two last processes assumes that in the conditions of market economy any bank exists only because there is a developed demand for its products. From this it follows that depending on environment analysis results, and also mission of bank, it develops specific product strategy, adhering to it during the activities. At the present stage special emphasis in case of development of similar strategy is placed on development and creation of a number of new banking products. It is regarded as indispensable means of stabilization of the functioning, preserving and hardening of competitive line items of bank and leads to economic growth.

Considering the fact that the bank as the subject of the market in planning process and implementation of innovative activities cannot exclude influence of the environment of an environment, process of the analysis assumes studying of three of its components (see fig. 3):

- internal environment;

- micro-environments (direct environment);

- macro-environments. 


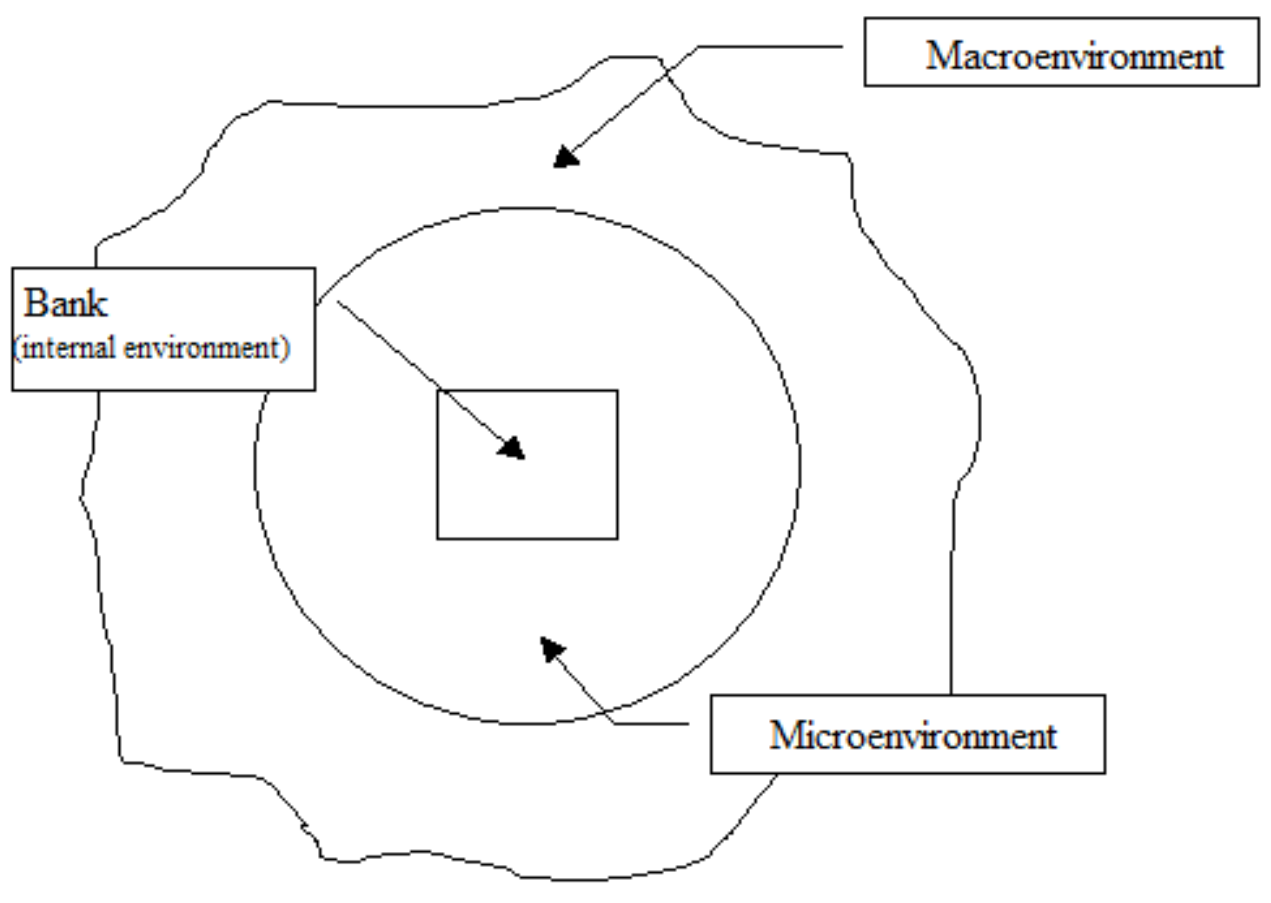

The internal environment of bank is not part of an environment, but the element which constantly interacts with other components, constantly is exposed to their influence and includes that potential which the bank in the activities has. This component includes set several a component, it forming:

- organizational component (internal regulatory base of bank, organizational structure, hierarchy of subordination, rights and responsibility);

- financial component (structure of financial flows, resource and investment base);

- personnel a component (job management, stimulation, structure of relations in collective)

- production component (production and economic structures of bank).

Micro-environment, or as it is referred to as still, a direct environment - area of direct and fixed contact of the internal environment of bank, includes consumers of banking products, partners, competitors, the market of labor power. The structure of relations of these subjects which is under the influence of geographical, demographic and social and psychological factors directly determines availability or absence at bank of additional opportunities of development and is "ground" for implementation of its activities.

The macro-environment of bank creates general terms of functioning of bank and its interaction with external environment. Its components are the factors which are not exerting specific impact on activities of credit institution, but determining its positioning in the markets, a product orientation, other opportunities for business. In the analysis of this component the following cuts of the public relations are considered: all-economic, political, standard and legal, social and technological.

Process of determination of the purposes implies creation and determination of general reference points of innovative activities of bank during which the credit institution in each separate timepoint is fixed on achievement of the certain characteristics which are for it favorable and desirable and to which achievement these activities are directed. The purposes established by bank determine quantity and essence of the proceeding innovative processes and are subdivided on short-term and long-term. Long-term usually imply their achievement on completion of any stage of development of the bank determined by strategic tasks i.e. three-five years. Short-term objectives vary depending on tactical tasks of bank, and the term of their achievement can fluctuate from one-two months to onetwo years. Such division of the purposes is not accidental since. practice of innovative activities shows that longterm goals are initially less concretized and find necessary disaggregation only at the last stages of their achievement. 
Long-term goals are often coordinated to set short-term which consecutive or parallel achievement means as a result achievement and a long-term goal. With respect thereto, and also with the need of more flexible approach to management of innovative activities of bank which has amplified owing to the increased dynamism of the financial markets it is possible to note the following: long-term goals, unlike short-term, periodically are subject to adjustment in the course of their achievement.

The purposes determined in the course of implementation of innovative activities belong to all spheres of functioning of credit institution and work with clients: to investment, resource and personnel policy of bank, its organizational, economic and production structures, etc. The purposes are established after judgment of analysis results of the environment of interaction and acceptance of a number of the strategic decisions concerning a further way of development of all credit institution in general. Each purpose depending on scale and complexity of a problem determines origin of one or several innovative processes directed to its achievement. However, from in what way goal achievement process will go, the probability of bank to achieve success in this direction depends.

With respect thereto selection process of innovative strategy on which it depends to what course innovative activities of bank will be directed receives relevance. The resource base of one credit institution is other than other credit institution rather strongly, the available intellectual personnel potential is also not identical. Quality of the analysis of environment, and, the main thing, the definiteness of its results which is expressed in identification of additional opportunities for further fixing and expansion of the line items in the market at each separately taken bank different. Each credit institution chooses the unique set of means, methods, the principles and actions for achievement of the set goals, i.e. determines the strategy. The term "strategy" is treated by modern economic science as "the set governed for decision making by which the organization is guided in the activities" 4. Otherwise the concept of strategy can be treated as the main direction of movement of the organization in the long term leading to the planned purpose.

Strategy selection process, logically following process of determination of the purposes, brings together ideas of a management of credit institution of the available and expected opportunities, its strong and weaknesses, potential, etc. Its result is the decision on when and how exactly it is necessary to initiate innovative processes what resources will be involved in process of their passing what nature of innovative activities what moments of functioning of bank will be involved in it, etc. will be. From this it follows that strategy development is one of the most important elements in structure of innovative management in banks.

\section{MANAGEMENT OF INNOVATIVE ACTIVITIES OF BANKS}

In general, any innovative process in bank has cyclic nature. The activities having innovative process in the basis logically break up to the separate accurately expressed elements realized chronologically consistently and often and different divisions of bank. Schematically the cycle of innovative process looks as follows. Each stage of innovative process is intended for the solution of a separate certain task (Aksiyev T.T., 2012, 38-39):

- emergence of idea and problem definition of the forthcoming innovative process.

- scheduling of the actions and actions necessary for goal achievement.

- determination of resource requirement (personnel, technological, material), necessary for implementation of innovative process, statement of local tasks before contractors.

- carrying out by contractors (the bank employees responsible for carrying out innovative actions) of the actions connected with implementation of the tasks.

- control, the analysis and adjustment of the carried-out actions. An efficiency evaluation of the innovative project, innovative management decisions, extra analytical work for refining of the plan of the subsequent actions for implementation of results of innovative process.

The conducted researches of a problem of innovation management have shown that in the majority of commercial banks of Azerbaijan the management is oriented to the solution of the current, but not strategic tasks which, are generally connected with financing of trade and game in the financial markets. In addition quality of management in domestic banks most often does not correspond to world level and national requirements of development of a bank system. Therefore strategic interests of development of banking require carrying out reform of commercial banks. 
The reform purpose - to lift quality of management in commercial banks to the level of world requirements on the basis of the thought-over innovative policy. Inadequacy of development of commercial banks to world practice slows down more effective development of a bank system now in general and, respectively, reduces its role in raising of real production sector of the country.

The analysis of organizational structures of commercial banks shows that the majority of them has linearly - functional structure with high extent of centralization of management. On dynamics of innovative processes the great influence is exerted by the organization of work of bank clerks, traditional for credit institutes, which relies on the following rules principles (Aksiyev T.T., 2012, 38-38):

- to work in strict accordance with the available instructions.

- $\quad$ to avoid any mistakes and failures.

- not to show an initiative, and to wait for specifying from above.

- to work only within the charged work.

- to think, mainly, of own safety.

In other words, the traditional corporate culture does not stimulate the person to creativity, does not develop at it flexibility, independence, aspiration to risk, i.e. the qualities in many respects constituting an essence of entrepreneurial nature.

Researches show that tendency to innovations, use of services of scientific and independent consultants is directly pro rata to the level of the organization of creative work of bank clerks.

Meanwhile, in development of the advanced commercial banks two tendencies are accurately looked through: first, search of new organizational schemes and methods of strategic management on the basis of innovative entrepreneurial approach; secondly, gradual transformation (under the influence of the competition) considerable part of banks in financial and intermediary commercial organizational structures on the basis of expansion and development nonconventional (and, actually, non-bank) transactions (trust, leasing, consulting, trade, insurance, etc.).

Both of these tendencies cause flows of innovations which can cardinally change a view of a role of banks in social and economic life of society.

\section{CONCLUSION}

As a result of the executed research it is possible to formulate conclusions and recommendations of scientific and methodical and practical nature.

- The innovation is special goods which cannot use without a certain minimum of scientific knowledge, professional competence and knowledge. Not to realize an innovation without the corresponding preliminary preparation and retraining. A peculiar feature of such goods, its capability to unrestricted multiplication (animation) of the income is. Banks in the developing new technological and economic way should look for new points of application of the equity. Investments into the new technologies allowing getting profit on not excised intellectual potential of society can become such alternative and highly profitable points.

- Now the bank system of Azerbaijan gravitates more to continental model an confirms a number of tendencies in development of a bank system of the country. There are processes of centralization, merge and absorption of banks that leads to strengthening of line items of large banks. Sharply growth is slowed down numbers of credit institutes, the amount of bankruptcies and revocations of licenses increases by the right of banking activity. From the point of view of development of an investment potential process of concentration of a banking capital is a favorable tendency as small and small banks are capable to provide accomplishment of current transactions and short-term commercial lending, but liquidities for implementation of the majority of investment projects do not possess sufficient financial resources.

- The major and fundamental aspect, the choice of tools and the mechanism of attraction of financial resources, for financing of innovations is. Building-up of own means by bank, and also new financial instruments by means of which it is possible to raise funds of legal entities and physical persons, will significantly increase a flow 
of investments into innovations. If the bank is not able to finance this or that innovative project neither at the expense of own means, nor at the expense of the deposit base, then it can issue on its own behalf or on behalf of the innovative entity a bonded loan. Otherwise, to act in a role - the underwriter, in case of share placing or in case of placement of corporate bonds. The innovative entity will already act as the issuer, and bank the investor undertakes a mediator role of the certain amount guaranteeing the redemption for himself and a rest public placement in the public financial market.

\section{REFERENCES}

[1] Abramov R.(2009) Features of budget financing of innovations in regions, Finance and the credit.No-37.

[2] Balabanova I.T. (2001)."Banks and banking" SPb.: St. Petersburg,

[3] Banks and banking / Under the editorship of Balabanov I.T. SPb.: St. Petersburg, 2001.

[4] Banking: a strategic management / Under the editorship of V. Platonov,

[5] Banking: The textbook / Under the editorship of O. I. Lavrushin. M.: Finance of an istatistik, 1999.

[6] Vikulov V. S. (2001), Innovative activities of credit institutions in Russia and abroad No. 1/.

[7] Goldstein G. Ja. (1998), Innovative management. — Taganrog: TRTU publishing house,.

[8] Goldstein G. Ja. (2004), Strategic innovative management: Education guidance. Taganrog: TRTU publishing house,

[9] Gusev K. N.(2010), Innovations in Russia: problems and prospects, Banking. - No. 1.

[10] KNORUS M. (2004). Money, credit, banks: The textbook / Under the editorship of O. I. Lavrushin. 3rd prod.reslave.and additional -

[11] Drasikova E. (2005),An assessment of credit risk in bank branches.//Bank messenger.No. 7..

[12] Druker P.F.(2007)[= M. Business and innovations]. — "Williams",

[13] Kadyrov A.N. (2002). A technique of determination of category of risk of the borrower for management of risk level of a credit portfolio of bank.//Finance and credit.No. 7.

[14] Kallaur P. V. (2007). Development of a risk management in banks.//Bank messenger.No. 31.

[15] Konyaeva.A. (2010).Low Budget management//Banking. No. 8.

[16] Lebedev P. (2009). Management of money to the touch.How to live without budget"//the Finance director. No. 1-2.

[17] HigginsM. (2001) 2nd prod. M.: Consult-banker..

[18] Scientific library of theses and abstracts : http://www.dissercat.com

[19] Pelevina K. (2009).A role of a venture capital in financing of innovations, the Bulletin of institute of economy of the Russian Academy of Sciences.No. 3.

[20] Principles of credit risk management. Basel committee on banking supervision//Bank messenger. No. 30.2007.

[21] Rose Village of St. Petersburg. Bank management: The lane with English from the 2nd edition. M. Case of Ltd., 1995.

[22] Rudko M.(2011), to "Bases of information technologies", Final work - the Belarusian State University.

[23] SavonCentury.Creation of risk management system in bank.//Bank messenger.No. 7. 2005.

[24] Statistics of science and innovations. The short terminological dictionary / Under. L.M. Gokhberg edition - M.: Center of researches and statistics of science, 1996.

[25] Terenina A.S., Tonysheva L.L. (2012). "Theoretical Bases of Innovative Technologies in Banking Activity", IV International student's electronic scientific conference "STUDENT'S SCIENTIFIC FORUM 2012" http://www.rae.ru/forum2012/21/654

[26] Tychinsky A. V. (2006) Management of innovative activities of the companies: modern approaches, algorithms, experience. Taganrog: TRTU.

[27] Fatkhutdinov R. A. (2008).Innovative management: textbook / R. A. Fatkhutdinov. - M.: St. Petersburg,

[28] HargadonA.(2007).Innovation management. Experience of leading companies = How Break-through Happen. The Surprising Truth About How Companies Innovate. - M.: "Williams". 